Martyna Pryszmont-Ciesielska

\title{
„JA” BADACZA W PODEJŚCIU AUTO/BIOGRAFICZNYM UJĘCIE METODOLOGICZNE
}

Czy nie tworzymy nieświadomie własnych indywidualnych mitów, według których porzadkujemy doświadczenie? Nie moga mieć one - jako takie - wiele wspólnego z tak zwana obiektywna rzeczywistościa, ponieważ nasza świadomość nie jest ze swej natury niczym samym $w$ sobie, pozbawionym odniesien, lecz jest zapośredniczona przez system nerwowy, postrzeganie, emocje, doświadczenie i w końcu język.

Olga Tokarczuk (2012: 184)

\section{Wprowadzenie}

Biografia jest jednym $z$ najbardziej inspirujacych źródeł wiedzy na temat świata społecznego. W moim przekonaniu, stanowi ona również ważny, a zarazem złożony czynnik kształtujacy naukę. Przez pryzmat biografii możemy się przyglądać własnej aktywności naukowej, budując w ten sposób fundament refleksyjnej praktyki badawczej. W tym rozumieniu, osobista biografia wyznacza ramy poznania naukowego, stając się przedmiotem prowadzonych poszukiwań badawczych. Prezentowany tekst stanowi próbę metodologicznego uzasadnienia dla tego typu praktyk. Moim celem jest wstępna rekonstrukcja dróg, jakimi może zmierzać badacz przekonany o sile oddziaływania własnej biografii na podejmowana aktywność naukowa. Przyjmując taka właśnie pozycję, chciałabym przede wszystkim poszukać odpowiedzi na następujące pytanie: 
w jaki sposób zaznaczać i umieszczać biografię podmiotu poznającego $\mathrm{w}$ procesie badawczym?

Rozważania zacznę od wyjaśnienia różnicy między podejściem autobiograficznym a auto/biograficznym, następnie przybliżę perspektywę auto/biograficzną na tle wybranych paradygmatów i podejść badawczych, wreszcie - spróbuję wyróżnić i dookreślić formy relacjonowania autobiograficznego, $z$ jakich jesteśmy $w$ stanie korzystać, współtworząc dyskurs naukowy (ze względu na własne usytuowanie dyscyplinarne (pedagogika) ograniczam go do przestrzeni nauk społecznych i humanistycznych). Tekst zakończę wskazaniem paru wątpliwości odnośnie do ograniczeń wynikających ze stosowania perspektyw autobiograficznej i auto/biograficznej.

\section{Rozumienie podejścia autobiograficznego i auto/biograficznego}

Zauważane w ostatnim czasie szerokie zainteresowanie badaniami biograficznymi nie ominęło i mojej rodzimej dyscypliny, a mianowicie andragogiki (Bron 2009: 37). Z pewnością wiąże się to $z$ docenieniem nieformalnych procesów oraz aspektów uczenia się dorosłych, które towarzysza codziennemu życiu ludzi. Podejście to szczególnie chętnie wykorzystywane jest $\mathrm{w}$ badaniach nad całożyciowym uczeniem się dorosłych (Malewski 2010). Niemniej, jak pokazuja przykłady antropologii czy socjologii, tego typu badania maja znacznie dłuża historię (Tamże: 37). Dlatego, przez wzgląd na fakt, iż przedmiot tego rodzaju badań - „biografia” - jest różnie ujmowany przez kolejne (sub)dyscypliny naukowe, osadzone, co zrozumiałe, w odmiennych podglebiach teoretycznych, Danuta Urbaniak-Zając proponuje określenie „biograficznej perspektywy badawczej, w ramach której możliwe sa różne metody" (Urbaniak-Zająć 2011: 16-17).

Biograficzność jako przedmiot badań andragogicznych oznacza, najprościej rzecz ujmując, konstrukcję i rekonstrukcję życia człowieka dorosłego, zmagającego się $z$ wielorakimi trudnościami i przeszkodami (Alheit 1995); objawia także zdolność do projektowania życia w zależności od sytuacji i kontekstu (Alheit 1995). Biografia wyrażana jest przez autobiograficzna relację, która przyjmuje formę narracji. Zdaniem Anny Gizy-Poleszczuk, z autobiografia mamy do czynienia wtedy, gdy ktoś intencjonalnie przekształca zbiór doświadczeń w sensowna całość; jest więc ona zależna od jednostkowej świadomości, powołującej ja do „życia” w akcie opowiadania 
(Giza-Poleszczuk 1990: 96). W świetle powyższych ustaleń spotkanie $z$ „autobiografia” to spotkanie $z$ (od)tworzonymi przez naszych badanych historiami ich życia. Prawdopodobne jest też uruchomienie własnej autobiograficznej refleksji i narracji przez badacza. W tym przypadku występuje on w podwójnej roli: obserwatora życia „innych” oraz auto/obserwatora, budującego własną historię życia. Badanie społeczne dopuszcza tutaj rozciagnięcie granic poszukiwań, przy założeniu, iż przedmiotem badań sa tak „(mikro)światy” badanych, jak i badacza; rozszerza ono również perspektywę analizy i interpretacji - przy wyborze podobnego rozwiąania doświadczamy bowiem swoistej „hermeneutycznej fuzji horyzontów”, oznaczającej akceptację różnorodności perspektyw poznawania świata przez uczestników badań (badacza i badanych). Ważnym aspektem jest także wzajemne (re)konstruowanie swojej „biograficzności” przez oba podmioty. Pisząc o sobie, nie sposób przecież nie czynić odniesienia do życia innych (Stanley 1992, cyt. za Miller 2003: 122). Liz Stanley zwraca uwagę na wzajemną relację między konstruowaniem naszego życia poprzez tworzenie autobiografii a konstruowaniem życia innych za pomoca biografii. Stąd, w przygotowywanym przez badacza obrazie historii życia osób badanych, zawiera się i odbija historia jego własnego życia (Tamże). Istotną rolę odgrywa w tym podejściu ,ja” autobiograficzne - czynnik uwypuklający kontekstualny i sytuacyjny charakter wiedzy badacza (Tamże).

Każda biografia badacza posiada indywidualną trajektorię, wzdłuż której przebiegaja różne wydarzenia życiowe, w tym także te dotyczące aktywności naukowej. Ta ostatnia jest „ścieżka wzdłuż której podróżuja jednostki, aby zaspokoić swoje roszczenia do rozumienia oraz zrealizować ponadindywidualne cele poszukiwań badawczych" (Usher, Bryant, Johnston 2001: 14). „Ja” badacza, zdaniem Robina Ushera, Iana Bryanta i Rennie Johnstona, ukształtowane jest kulturowo, historycznie, społecznie i posiada dwa wymiary: techniczny i doświadczeniowy. W obu wariantach badacz występuje w roli podmiotu - autonomicznej jednostki. Autonomia badacza w technicznej trajektorii badań rozciaga się na „arenę” badań, tj. dotyczy projektowania i realizowania czynności badawczych. W tym sensie „uwalnia się" on od instrumentalizmu strategii i metody badawczej. Z kolei wymiar doświadczeniowy obejmuje dwie jakości: sytuacyjne i dyspozycyjne. Struktura ,ja” badacza, podkreślają autorzy, kierunkowana jest zarówno przez właściwe jej dyspozycje (np.: cechy osobiste, entuzjazm, energia, poziom frustracji itd.), jak i zmieniajace się w czasie czynniki sytuacyjne (Tamże: 15, 16). Na trajektorię „ja” badacza składają się także „wydarzenia (nie)codzienne”. Część z nich 
przyjmuje postać epifanii, czyli momentów kryzysowych, życiowych „przełomów”, „zwrotnych kryzysów” (Kafar 2011: 44-45). Marcin Kafar, odwołujac się m.in. do myśli Normana K. Denzina podkreśla, że transformujący charakter doświadczenia epifanicznego stanowi konsekwencję świadomego uczestnictwa podmiotów w świecie społecznym. Jednocześnie, różnorodne przeżywanie epifanii wynika $z$ przypisanych temu doświadczeniu atrybutów, tj.: nagłości, dysproporcjonalności i „duchowości” (por. Tamże: 45-51).

Widać więc, iż uwarunkowania autobiograficzne badacza stanowia, obok epistemologicznych i aksjologicznych, istotne zaplecze (samo)wiedzy podmiotu poznającego (Pryszmont-Ciesielska 2008). Świadomość istnienia wymiaru biograficznego, na który składają się m.in.: historia życia, kultura, język, doświadczenie, umiejscowienie $\mathrm{w}$ świecie i w społeczeństwie, dyskurs, któremu badacz podlega/ uprawia, jest (powinna być?) integralnym etapem każdego projektu badawczego. Właśnie $\mathrm{w}$ tym horyzoncie badacz dokonuje wyborów i podejmuje decyzje, mające niekiedy kluczowe znaczenie dla przebiegu całego procesu badawczego. Choćby $z$ tego powodu, aspektom autobiograficznym warto nadać odpowiednią rangę ważności, sytuując je w obrębie prowadzonych poszukiwaniach badawczych.

Zdarza się, że badacz decyduje się uczynić własna biografię najważniejszym źródłem wiedzy o interesującej go problematyce. Wówczas jego życie osobiste determinuje podejmowana aktywność badawcza, a czynności badawcze staja się drugoplanowe wobec procesu (re)konstruowania autobiografii - mówimy wtedy o stosowaniu perspektywy autobiograficznej (Pryszmont-Ciesielska 2009: 38). Innym rozwiąaniem jest przyjęcie przez badacza pozycji łączącej w równoważny sposób doświadczenia własne $z$ doświadczeniami badanych - ten drugi przypadek wiąże się $z$ uruchomieniem perspektywy auto/biograficznej (Tamże: 39).

W tym miejscu zasadnym staje się postawienie pytania, jakie tradycje i filozofie badawcze stwarzają szansę realizacji podejścia auto/biograficznego?

\section{Perspektywa auto/biograficzna w kontekście wybranych paradygmatów i podejść badawczych}

Spośród wielu filozofii wpisujących się w rozległą praktykę badań jakościowych, chciałabym pokrótce omówić dwa wybrane paradygmaty, w obrębie których refleksja auto/biograficzna ma do- 
niosłe znaczenie dla prowadzonych badań. Pierwszym $z$ nich jest tradycja paradygmatu krytycznego, gdzie badacz dzieli się wiedza na temat przesłanek stojących za podjęciem określonego typu badań (Malewski 1998: 39). Sprzyja temu subiektywistyczna epistemologia wyrażająca się m.in. w uznaniu, iż wyniki badań zapośredniczone sa przez bliskie badaczowi wartości (Kubinowski 2010: 38). Wobec tego zyskuje on możliwość opowiedzenia o tym, jakie czynniki pozanaukowe ukształtowały jego światopogląd badawczy. Szczególnie docenione zostaje uczenie się $z$ codzienności oraz akceptacja dla włączania indywidualnych doświadczeń do procesu poznawczego. Zasadnicza cecha paradygmatu krytycznego jest refleksyjne nastawienie do rzeczywistości społecznej i obejmującego ja procesu poznania. W ramach praktyk refleksyjnych badacz zyskuje m.in. szansę „prześwietlania” swojej biografii - wiedzy, doświadczenia, światopoglądu itd. - pod kątem tych czynników, które oddziałuja na tok prowadzonych badań. Wspólny udział podmiotów w przedsięwzięciach badawczych jest także okazją do wzajemnego dzielenia się i uczenia się $z$ tego, co osobiste.

Druga $z$ tradycji myślenia dopuszczająca obecność perspektywy auto/biograficznej jest paradygmat postmodernistyczny ${ }^{1}$, zakładajaccy - w warstwie ontologicznej - iż świat zbudowany jest z niezliczonej liczby mikroświatów społecznych (Tamże: 42). Każdy $z$ badaczy jest „zakorzeniony” lub zwiazany $z$ wybranymi "mikroświatami”. Postmodernizm dopuszcza relatywizm poznawczy i akceptuje wielorakie formy „bycia” i pisania o świecie. W tego typu rozwiazaniach badawczych ważkie stają się sposoby, jakimi posługuje się autor konstruując teksty oraz to, jaką wyznaje on „politykę poznawczą" (Tamże: 54). W efekcie badacz występuje w roli przedmiotu badania, a jednym $z$ celów procesu badawczego jest ustalenie relacji „między procesem i produktem poznania” (Tamże: 45).

„Ja" badacza może zostać wpisane w każde podejście o charakterze jakościowym, przy czym refleksja ta zyskuje różny status

${ }^{1}$ Nazwy tej używam za Mieczysławem Malewskim. Zdaję sobie sprawę $z$ faktu, iż paradygmat ten znajduje się wciąż na etapie krystalizowania swojej filozofii i programu metodologicznego. Malewski (1998: 44) tłumaczy to następujaco: „Postmodernistyczny projekt detronizuje naukę instytucjonalną w jej dotychczasowym kształcie. W zamian oferuje ludzkiemu poznaniu pewne wizje. Sa one pozbawione podstaw metodologicznych w tradycyjnym rozumieniu, jakie wiążemy $z$ terminem "metodologia". Nie tworza one również paradygmatu w znaczeniu proponowanym przez Th. S. Kuhna”. $Z$ tego powodu odwołuję się do wybranego wattku tego paradygmatu, tj. uznania uwarunkowań autobiograficznych badacza za jeden $z$ najważniejszych aspektów prowadzonych poszukiwań badawczych. 
w prowadzonych poszukiwaniach badawczych. W zależności od celu badań da się ją uczynić albo pierwszoplanową (perspektywa autobiograficzna), albo też drugoplanową wobec wiedzy pochodzącej $z$ terenu badań. Jednocześnie, oba rodzaje wiedzy (osobista oraz pochodzaca $z$ terenu badań) moga $\mathrm{w}$ takim samym stopniu stanowić istotne $-z$ punktu widzenia badanych problemów - źródło poznania (perspektywa auto/biograficzna). Wybrzmieniu auto/biograficznemu wyjątkowo sprzyjaja podejścia: biograficzne, etnograficzne oraz badanie w działaniu ${ }^{2}$. Jaka wartość, z punktu widzenia osób badanych i przedmiotu badań, ma umieszczanie „ja” badacza w cyklu badawczym w/w podejść? Poniżej znajduje się Tabela 1., skrótowo obrazująca tę kwestię.

Tabela 1. Znaczenie wpisywania „ja” badacza w wybranych podejściach badawczych

\begin{tabular}{|l|l|}
\hline \multicolumn{1}{c|}{$\begin{array}{c}\text { Wybrane } \\
\text { podejście badawcze }\end{array}$} & $\begin{array}{l}\text { Znaczenie wpisywania ,ja" badacza } \\
\text { do podejśsia badawczego }\end{array}$ \\
\hline Biograficzne & $\begin{array}{l}\text { Badacz i badany wzajemnie (re)konstru- } \\
\text { ują swoje historie życia; poszukiwanie } \\
\text { sensów i znaczeń o życiu w narracjach }\end{array}$ \\
\hline Etnograficzne & $\begin{array}{l}\text { Badacz i badany wspólnie uczestnicza } \\
\text { i doświadczaja terenu badań; poszuki- } \\
\text { wania autoetnograficzne }\end{array}$ \\
\hline Badanie w działaniu & $\begin{array}{l}\text { Badacz i badany sa zaangażowani we } \\
\text { wspólne uczestnictwo i działanie; kry- } \\
\text { tyczna i refleksyjna postawa badacza wo- } \\
\text { bec własnego ,ja" }\end{array}$ \\
\hline
\end{tabular}

Źródło: opracowanie własne

Każde $z$ wyróżnionych podejść „zezwala” na wspólne działania i oddziaływanie na siebie obu podmiotów badania (badacza i badanego). W wyniku tej „aktywności” obie strony zyskuja sposobność

${ }^{2} \mathrm{~W}$ przypadku wybranych orientacji (biograficzna, etnograficzna, badanie w działaniu) zdecydowałam się zastosować termin „podejście”, ponieważ stanowią one całościowe propozycje badawcze. W zależności od przyjętego paradygmatu badań, precyzuja one kwestie związane ze strategia postępowania badacza w całym cyklu badawczym. Mowa tu o następujących etapach: formułowaniu problematyki badawczej, sposobach gromadzenia wiedzy, analizie i interpretacji uzyskanych materiałów, a także postawie badacza wobec przedmiotu badania, osób badanych i własnej aktywności poznawczej. 
do (re)konstruowania własnych historii życia oraz rozumienia swojego miejsca w świecie. Wpisanie „ja” badacza w cykl badawczy daje szansę na upodmiotowienie wzajemnych relacji, sprzyjając zarazem czerpaniu obopólnych korzyści $z$ dokonującego się spotkania i wpisanego w nie dialogu.

\section{Formy relacji "o sobie" - prezentacja refleksji autobiograficznej}

Praktyka pisania to, zdaniem Jacka Piekarskiego (2006: 118), „rodzaj czynności społecznej, w której dokonuje się unikatowy proces konstruowania znaczeń, poprzez który przestrzeń indywidualnego doświadczenia (prywatny sposób rozumienia) uzyskuje w tekście upubliczniona reprezentację". Biografia podmiotu poznajaccego stanowi (wy)twór światów społecznych badacza. W związku $z$ tym przyjąć należy, iż także praktyka pisania podlega społecznym odniesieniom. Myślę, że ważnym zadaniem badacza jest unaocznienie owej praktyki jako głęboko osadzonej w procesie badania. Służy temu adekwatna do przyjętego sposobu ujęcia danej problematyki forma pisania ${ }^{3}$, dzięki której badacz dokonuje aktu autobiograficznej prezentacji. Przy wykorzystaniu dostępnych gatunków literackich, dziennikarskich i artystycznych ${ }^{4}$, relacja autobiograficzna badacza przyjmuje postać pisemną.

W pierwszej kolejności badacz wybiera temat, na którym skoncentrowana jest pożądana forma relacji autobiograficznej. Przy wsparciu narzędzi literackich, badacz jest w stanie przygotować poemat, uchwytujący jego doświadczenia czy postawę wobec życia. Można się także pokusić o zbudowanie wypowiedzi narracyjnej, nadając jej fabułę, ukazująca własne losy badacza i kreująca na jego podobieństwo bohatera występującego w tymże opowiadaniu. Opowiadanie o życiu, w zależności od okoliczności, świetnie sprawdzi się również w reportażu. Relacja reportażowa powinna zawierać liczne opisy sytuacji, w które badacz - świadek tych sytuacji - angażuje swoich czytelników. Jeśli chcemy pokusić się o rytmiczne notowanie zdarzeń $z$ codzienności, wówczas $z$ pewnością warto skorzystać $z$ formy dziennikowej (w grę wchodzi także dziennik

3 „Forma pisania” to wybrany przez badacza sposób pisania o sobie.

${ }^{4}$ Opracowując poszczególne formy korzystałam ze słownika języka polskiego PWN (Stownik...). 
internetowy). Chcac natomiast skoncentrować się na selektywnie dobranych informacjach, polecane jest stworzenie życiorysu - zawarte tam zostana lapidarnie oddane zdarzenia, rozciagnięte na długim łuku życia zawodowego, edukacyjnego, rodzinnego itd. Natomiast w sytuacji, kiedy badaczowi zależy na tym, aby mocno wyakcentować swój pogląd najlepiej będzie napisać esej. Ostatnią $z$ form pisemnej wypowiedzi, jakie proponuję wyróżnić jest list - zawiera on wiadomość skierowana do ściśle określonego adresata. I w tym wypadku tematem sa wątki biografii badacza.

Formy tekstualne nie wyczerpuja oczywiście bogatego repertuaru relacjonowania autobiograficznego. Znakomitym ich uzupełnieniem, a niekiedy przydatna alternatywą są relacje wykorzystujace obraz i dźwięk. W tej grupie, w pierwszym rzucie należy wspomnieć o fotografii. Relacja autobiograficzna wsparta o zdjęcia obejmuje tak fotografie wykonane przez samego badacza, jak i przez osoby trzecie; moga to być źródła zastane oraz intencjonalnie tworzone. Podobnie jest w przypadku filmu. Badacz zyskuje, przy pomocy nawet krótkich utworów audiowizualnych, niepowtarzalną okazję oryginalnego świadczenia o własnym życiu. Sięgając po podobne rozwiązania, ważne jest, aby dokładnie opisać kontekst ich powstawania.

Nie zapominajmy wreszcie o jeszcze jednym interesującym kanale komunikacyjnym, jakim jest performans, np. przyjmujacy formę happeningu. Tabela 2. przedstawia wyszczególnione wyżej formy prezentacji autobiograficznej.

Tabela 2. Formy prezentacji autobiograficznej badacza

\begin{tabular}{|l|l|l|}
\hline \multicolumn{1}{|c|}{ PISEMNE } & OBRAZOWO-DŹWIĘKOWE & PERFORMANS \\
\hline Poemat & Fotografia & Happening \\
\hline Opowiadanie & Film & \\
\hline Reportaż & Fotoreportaż & \\
\hline Dziennik & & \\
\hline Życiorys & & \\
\hline Esej & & \\
\hline List & & \\
\hline
\end{tabular}

Źródło: opracowanie własne 


\section{Refleksje na zakończenie}

Obie perspektywy - autobiograficzna oraz auto/biograficzna - prócz niewatpliwych wartości dodanych, jakie wnoszą do procesu badania, posiadają i pewne wady, budzace wątpliwości co do ich pełnej przydatności metodologicznej. Pokuszę się zatem o postawienie kilku pytań, wskazujących ewentualne dalsze kierunki poszukiwania ograniczeń skrywanych $\mathrm{w}$ tychże perspektywach: $\mathrm{w}$ jaki sposób perspektywy te wyrażaja ukryta/jawną dominację podmiotu poznajacego, umożliwiając mu skolonizowanie terenu badańs? W jakim sensie sa one kolejnym projektem mającym wyjaśnić i tym samym kontrolować po ludzku zdeterminowany świat? Wreszcie, w jakim sensie wyrażają one tęsknotę (badacza) za życiem wolnym od nauki instytucjonalnej, tęsknoty za byciem podmiotem - autonomiczna, twórcza jednostka $-\mathrm{w}$ świecie zdefiniowanych paradygmatów, uprawianych dyskursów i narzuconych ról?

\section{Bibliografia}

Alheit P.

1995 Biographical learning. Theoretical outline, challenges and contradictions of a new approach in adult education, [w:] P. Alheit (red.), The Biographical approach in European adult education, Wien, s. 57-74.

Bron A.

2009 Biograficzność $w$ badaniach andragogicznych, „Dyskursy Młodych Andragogów", nr 10, s. 37-54.

Foucault M.

1998 Nadzorować i karać. Narodziny więzienia, przeł. T. Komendant, Warszawa.

Giza-Poleszczuk A.

1990 Autobiografia. Między symbolem a rzeczywistościa, „Kultura i Społeczeństwo", t. 34, nr 1, s. 95-112.

Kafar M.

2011 Biograficzne epifanie $w$ kontekście tworzenia podstaw jakościowego kolektywu myślowego [w:] M. Kafar (red.), Biografie naukowe. Perspektywa transdyscyplinarna, Łódź, s. 37-66.

5 Wybór omawianych perspektyw można rozważać w kontekście Foucaltowskich kategorii władzy/wiedzy. W tym sensie podmiot poznający, podlegajacy określonym dyskursom społecznym, dąży do panowania nad terenem badań (Foucault 1998; por. też Pryszmont-Ciesielska 2006: 72). 
Kubinowski D.

2010 Przyrodnicze i humanistyczne podstawy badań pedagogicznych, [w:] S. Palka (red.), Podstawy metodologii badań w pedagogice,

Malewski M. Gdańsk, s. 29-44.

1998 Teorie andragogiczne. Metodologia teoretyczności dyscypliny naukowej, Wrocław.

2010 Od nauczania do uczenia się. O paradygmatycznej zmianie $w$ andragogice, Wrocław.

Miller N.

2003 Auto/biografia $w$ badaniach nad edukacja $i$ uczeniem sie całożyciowym, przeł. Z. Sidorkiewicz, „Teraźniejszość - Człowiek - Edukcja”, t. 21, nr 1, s. 121-140.

Piekarski J.

2006 O drugoplanowych warunkach poprawności praktyki badawczej w pedagogice - perspektywa biografii, [w:] D. Kubinowski, M. Nowak (red.), Metodologia pedagogiki zorientowana humanistycznie, Kraków, s. 97-126.

Pryszmont-Ciesielska M.

2006 Two metaphors of a meeting with culture - autobiographical researcher's perspective, „Kultura i Edukacja”, nr 4, s. 70-76.

2008 Badacz wobec kultury - o „podróżowaniu”, czyli o badaniu świata społecznego, [w:] W. Jakubowski (red.), Kultura i edukacja (konteksty i kontrowersje), Kraków, s. 41-53.

2009 Podejście auto/biograficzne $w$ badaniach nad edukacja - propozycja metodologiczna, „Teraźniejszość - Człowiek - Edukacja", nr 2, s. 37-49.

Słownik...

Słownik Języka Polskiego (wydanie internetowe dostępne pod adresem: www.sjp.pwn.pl).

Tokarczuk O.

2012 Moment niedźwiedzia, Warszawa.

Urbaniak-Zajacc D.

2011 Biograficzna perspektywa badawcza, [w:] E. Dubas, W. Świtalski (red.), Uczenie się z (własnej) biografii, Łódź, s. 5-27.

Usher R., Bryant I., Johnston R.

2001 Podmiot poznajacy $w$ badaniach edukacyjnych (perspektywa postmodernistyczna), przeł. A. Wierzbicka, „Teraźniejszość - Człowiek - Edukacja”, t. 14, nr 2, s. 83-97. 